DOI: 10.18468/rbli.2020v3n1.p56-84

\title{
Lingering relevance: the discourse-driven emergence of the perfect or anterior construction in Kalapalo, Southern Cariban (Brazil)
}

Ellen B. Basso

School of Anthropology

University of Arizona

Abstract. The perfect or anterior in Kalapalo (Southern Cariban) plays important discourse driven roles in several narrative and ceremonial speech genres. It appears to be a relatively recent feature compared with descriptions of morphosemantic cognates in Northern Cariban languages. The basic perfect morpheme atehe, PER is a syntactically and semantically multifunctional hybrid or mixed element, having both adverbial and verbal features. A phonologically separate postposition, atehe references a) the consequences of prior events involving participants focused in a narrative; b) later situations and experiential consequences of those situations; and c) stance-creating situations appearing in quoted conversations.

Keywords: Discourse-Driven; Cariban Languages; Kalapalo; .

\section{Introduction}

This paper describes the discourse-driven emergence of the perfect or anterior domain in Kalapalo, a Southern Cariban language spoken in the Alto Xingu region of Mato Grosso, Brazil (kuik 1246) by approximately 670 people living in 10 local groups (GUERREIRO, 2013). The domain plays important pragmatic roles in narrative and ceremonial ritual speech, appearing to be a relatively recent feature given what has been described for morphosemantic cognatic features in Northern Cariban languages.

The perfect or anterior is a domain that functions to express the external temporal relation between two time points, one of which is a prior event or situation (BYBEE et. al., 1994, p. 52; BYBEE, 2015, p. 141; COMRIE, 1976, p. 52; DAHL, 1985, chapter 5; GIVÓN, 2001, p. 293-296; STASSEN, 2003, p. 255). As Dahl and Velupillai (2013, p. 1) explain, the perfect 'is used to express events that took place before the temporal reference point but which have an effect on or are in some way still relevant at that point'. Givón and Stassen regard deferred or lingering relevance as the most important perfect implicature.

Linguists describe the perfect as a multifunctional morpheme (COMRIE, 1976, p. 56; DAHL; VELLUPILLAI, 2013; RITZ, 2012, p. 881). Research on the perfect in a wide range of languages, especially by Dahl (1985) and Bybee et. al. (1994) and other references cited by Ritz (2012), has led to a strong interest in the sources of these morphemes and the relation of the perfect as an original source or an ongoing path to the development of perfective aspect and to past tenses. Work has shown that sources of the perfect are resultative constructions (RITZ, 2012, p. 900), nouns, possessives, and 'already' words (DAHL; VELLUPILLAI 2013, p. 2), active verbs, 'movement from' and 'finish' words (BYBEE, 2015, p. 142). Following Comrie (1976), Stassen (2003, p. 256) and Dixon (2012, p. 31-32) write of a close connection between the perfect and the perfective aspect because of an association of the perfect with completed action and its consequences. Yet Bybee (BYBEE et. al.,1994; BYBEE, 2015, p. 141), who uses the term 'anterior' to avoid confusion between 'perfect' and 'perfective', notes the 'anterior' is "not used to narrate sequences of events, so it is different from the past or the perfective". 
Thus, while some writers may describe the perfect as an aspect (PAYNE; PAYNE, 2013) or a tense (ALLAN, 2009, p. 1000), the Kalapalo perfect is not equivalent to either one nor is it an analytic perfect as found in languages of Europe (RITZ, 2012).

Contributing to cross-linguistic knowledge of this problematic category, I present here my analysis of how that functional domain is encoded in Kalapalo, one of two varieties of Southern Cariban spoken in the Alto Xingu ${ }^{1}$. Kalapalo is a head marking agglutinative OV variety with some fusional features resulting in syllabic reduction (BASSO, 2014; 2020). I follow Franchetto's analysis of Kuikuro, the other variety (FRANCHETTO, 1990; 2006; FRANCHETTO; SANTOS, 2010) concluding that boundaries between verbs and nouns (and to a lesser extent adverbs) are not strict. In both Kalapalo and Kuikuro there are shared pre-categorial roots, pronominal prefixes, possessive suffixes, plural concordance suffixes, and certain aspectual suffixes (BASSO, 2020), as well as a large number of enclitics (BASSO 2014; 2020). Derivational structures are common, as in other Cariban languages. Kalapalo is without explicit past, non-past or present marking on the verb, but with immediate/anticipated and distant/ potential future tenses. While there are no explicit past tense markers in Kalapalo, in several ways (described below) degrees of pastness or anteriority are implied with the marking of perfective and imperfective aspects on both verbs and nouns. The Kalapalo perfect is thus particularly interesting insofar as it relates 'the continuing present relevance to a event in the past" (COMRIE, 1976, p. 52). The examples used in this paper show the perfect appearing: a) to reference the consequences of prior events involving participants focused in the narrative; b) with regard to later situations and experiential consequences of those situations; and c) in quoted conversations involving stance-creating situations. Especially interesting is the differential role of participants in the variety of perfect uses; how they affect, and are affected by, the particular situations in which they exist and act, as when for example a speaker rejects the listener's request to do something or if a speaker believes the listener doubts a causal explanation connected to mythic time. Examining extended clause chains, building on syntactic and grammatical evidence from quoted conversations and didactic speech is helpful for understanding such a speaker's current or future participation (or negation of their role) in a perfect situation. Other questions of interest that will be explored here are a) how a 'prior situation' is referenced and b) how future and negative morphemes are used with anterior constructions.

The basic Kalapalo perfect construction is a phonologically separate postposition atehe, PER. Atehe references results or experiences of dynamic situations, and persistent states or settings. The morpheme follows a verbal or nominal clause, or occurs in a high topic clause-initial context, following the anaphoric focus demonstrative ule ('as for that'), AFR. Atehe may also follow taxis (JAKOBSON, 1971; XRAKOVSKIJ, 2016) clitics on the verb, interclausal switch-reference markers with nominal and verbal switch-reference functions (IRM), and verbal and nominal perfective, imperfective and habitual aspects $^{2}$. My recorded data reveal forty-five examples of atehe in two genres:13 of a total of 94 examples

1 These data were recorded during my research in the Kalapalo Alto Xingu communities of Aifa and Tangugu between 1966-1989. They are available from the Archives of Indigenous Languages of Latin America, University of Texas, Austin Texas. <ailla.utexas.org/islandora/object/ailla\%3A124374>

2 There are several possible cognates in other Cariban languages. Derbyshire calls the Northern Cariban Hixkaryana -txhe ('after') a 'time adverb' (1985, p. 48; p. 241), which is suffixed to Hixkaryana active verbs, and to the 'be' verb -exe in his example. Carlin (2004, p.501-505) writes about the Northern Cariban Trio de-verbal nominalizing suffixes htao and ahtao which reference the 'status of events, etc. in relation to specific periods of time', and tuwë as expressing the notion of 'anterior'. Payne and Payne (2013, p.220; p. 404) describe two aspectual suffixes on the Northern Cariban Panare verb as 
of narrative discourse (between 13-14\%), included in quoted didactic and conversational speech and in all 7 recorded examples of leaders' ceremonial talk (100\%). Another important genre, affinal civility, does not include atehe as far as I could tell from my field observations (BASSO, 2007). The speech of two generations of Kalapalo speakers are represented in my recordings of the two genres in which atehe appears. In this essay examples of atehe in 13 narrated and 5 ceremonial speech performances are used.

Atehe seems to function adverbally for four reasons. First, the clause final and argument postpositions of atehe are the same as most Kalapalo adverbs; atehe frequently follows the perfective inflection -nig' of the stative equative 'be' verb $a-$, EOS, and follows same and different event IRM. Second the possible inflection tehe has no other observed presence in Kalapalo. Atehe thus appears to be a deverbal adverbialization originating from EQS, perhaps suffixed by an archaic inflection (tehe). While currently atehe operates as a temporal adverb, there are examples which support a claim for a continued 'be' verb function. In these examples atehe is inflected with pronominal prefixes, which do not otherwise occur with Kalapalo adverbs, but occur on both verbs and possessed nouns. On atehe, these prefixes may be part of an archaic construction of the EQS morpheme $a$-considered (as currently) the verbal stative equative root and tehe an inflective perfect. If so, atehe thus appears to be a 'hybrid' or 'mixed' type of word (Comrie and Thompson 2007) arising from the common appearance of identical morphosyntactic features involving verbs and nouns in Southern Cariban. Several Northern Cariban languages have atehe cognates but with the exception of Payne and Payne, linguists writing about these languages do not describe any forms as 'perfects'. Thus the Kalapalo pragmatic functioning of atehe appears to be relatively recent and may have emerged with perfect meaning in connection with certain cultural features of narrative and ceremonial discourse. The syntactico-semantic adverbial functions may follow other current adverbials.

In Section 2, using examples from my recorded research materials, I describe grammatical morphosynactic features of atehe to illustrate the apparent developmental features of this word. In addition to discussing the apparent development of the perfect morpheme, I examine the connections between Kalapalo perfect and perfective aspect; the uses of Kalapalo perfect and future marking; and the compatibility of perfect and negation in two types of contrastive perfect. The role of the perfect in this clause-chaining language and the syntactic relations of atehe and clause-chaining morphemes

'perfects', calling them an aspect 'expressing a state (i.e. a non-dynamic situation) in terms of the prior event that brought that state about'. Camargo's review of copular verbal morphemes in Northern Cariban languages and the Southern Cariban Ikpeng is suggestive, as she notes the copula roots ' -esi-, or variants -e(i)-, -et $\int \mathrm{i}$ commonly shared in these languages; and in Northern Cariban Macuxi, Amodio and Pira, a regular -anî or -enî and irregular -ai (CAMARGO, 2003, p. 135, p. 138). Camargo describes the Northern Cariban Wayana copular verb - a-/eha- inflected by several 'non-present' aspect/modality suffixes (there are also tense morphemes in this language). The differences between the two forms are claimed to be related to the time of utterance in such a way as there may be a link to whether or not there is speaker's connection to the past situation. The suffix -eha is associated with 'relação próxima com o estado no passado' ['close relationship with the past state'] (CAMARGO, 2003, p. 137-8). Yet no perfect is described as such by Camargo or other Cariban linguists other than Payne and Payne (2013).

At the time of this writing Bybee et.al. (1994, p. 54)) and Dahl and Vellupilai (2013) include Cocamo, Jivaro, and Tucano as the only South American languages in their samples explicitly recognized as having a perfect (Cocama and Tucano languages have perfects that are said to derive from verbs meaning 'finish'; Jivaro was included in the listing but a reference was not cited). Gildea (1998, p. 176-179) and Payne and Payne (2013) are more recent references, in which the Northern Cariban Panare perfect is associated with the perfective aspect (the Kalapalo periphrastic perfect with the 'be' perfective discussed in this paper). A reader states there are other Amazonian perfects but does not give references. 
will also be considered. In Section 3. I follow with examples of atehe taken from Kalapalo narratives, conversational discourse quoted in narratives, quoted affinal politeness speech events, and leader's ceremonial registers. I examine complex syntactic constructions including the discourse uses of atehe in clause-coordination and boundary marking functions. As the perfect also entails a pragmatic effect involving a decision or commitment based upon access to knowledge of the past, l examine the stanceconstructing and evidential uses of atehe in Section 4, and in Section 5 I present my conclusions and topics for further research

\section{Atehe morphosyntax and semantics}

The examples in this section illustrate the different functions of atehe that reference the consequences of prior events or situations; some examples show two periphrastic uses. Included are word order in the clause, and clausal types in which atehe appears. I also address the relation of atehe, aspect- and tense-marking morphemes, and pronominal prefixes in atehe constructions, as well as the relation of atehe with the high topic anaphoric demonstrative ule. I continue with interclausal same/switch reference (IRM) markers, and the compatibility of perfect and negation.

\subsection{The adverbial character of atehe}

Adverbialization is important in Kalapalo word-class changing derivations. There is a closed sub-set of underived adverbs, but many adverbs have been derived from verbs and more especially from nouns, demonstratives and de-verbal aspectual nominalizations. In Kalapalo, there are certain suffixed morphemes (-ki, -fi, -ti, -mi) distinctive to adverbializations. Many of these adverbial suffixes appear to have lost any adverbial (or precategorial) meaning. In this sense, atehe, with its hypothetical frozen tehe suffix, appears adverbial.

The place in clause constituent order is the most important and distinctive syntactic feature of the adverb. Most adverbs and adverbializations appear in segment final clausal position. When in final clausal position, adverbs modify the specific VP or NP they follow. In some cases, adverbs are clause initial, where they function as adjuncts of nominal (demonstrative, ideophonic) and verbal phrases (including 'be' verb phrases; the non-finite 'supine')

In example (1) with a clause-final adverbial construction, there are multiple adverbs in the adverbial phrase (boldface) where the adverb ekugu modifies the preceding adverb katote. VP is in brackets.

(1)

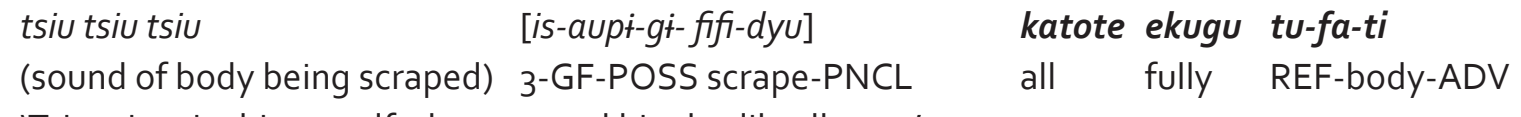

'Tsiu tsiu tsiu, his grandfather scraped him bodily all over.'

In Example 2, the adverbial phrase is clause initial. Atehe modifies this preceding adverbial phrase.

(2)

matehe (adverbial clause)*

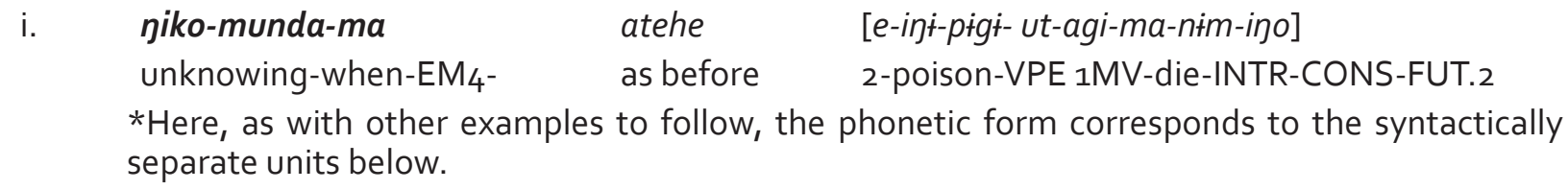


$e-t e f u=m b e=d y a$

2-stomach=SE=DA

'I don't know when it will be made to occur, but the consequence will be you'll poison yourself to death when it goes into your stomach'

nalifeke

$\begin{array}{llll}\text { ii. } \quad \text { teku-wa-lit } & \text { e-feke, } n=a l i & i \text {-feke } & \text { tu-fitsu-feke. } \\ \text { eat.hard.food-TRN-PNCL } & \text { 2-ERG, say.to=UT } & \text { 3-PRSP- } & \text { REFL-wife-PRSP3 }\end{array}$

'when you eat that stuff", he kept saying to her, to his wife.'

\subsection{The 'be' verb character of atehe}

The position of Kalapalo copular verbs in clausal constituent order is typically clause final. The stative equative root $a$ - EQS is a copular morpheme that references on-going states or conditions, and the end results of activity pertaining to A/S of active verbs. Senses of this root when used as an intransitive verb include: 'have', 'be as', 'reach', 'move to', 'keep' (specific predications include thought processes, temporal relations; event counts; and transient locations). EQS often appears as an initial clausal complement with the 'stative' nominalization suffix SN, a-ni,'have', and this gram itself may be adverbialized with the adverbial attributive suffix -pi,-PNCL as unipi,'possessed' A-ni appears in an adverbialization and as the root of a de-verbal nominalization, referencing alienable possession or association. Atehe itself never appears clause initially with such copular forms, but commonly follows any number of different Kalapalo nominals including free nouns, pronouns, de-verbal and de-adverbial nominalizations, ideophones, and ule (APR), the high topic clause-linking anaphoric demonstrative that references an anaphoric predicate. Most nominal arguments in atehe referenced clauses involve animate participants (including plant personages). Atehe is also often used with ule to link two clauses, the meaning being 'that's why', or 'as far as that is concerned'.

As seen in the next resultative examples, the perfect often follows continuous (3) and punctual (4) verb constructions. When in final clausal position, adverbs modify the preceding verb phrase, as atehe does in (3).

(3)

$\begin{array}{llll}k \text { wirgatehe* } & & \\ \text { ti-me=male } & \text { ige- } a & k w \text {-i-iga } & \text { atehe. } \\ \text { RO-FACS=DAD } & \text { IDEM-U } & 1+2 \text {-do-EP-CONT } & \text { PER }\end{array}$

'But why in the past didn't he make us differently from how we are now?'

Perfective inflections also occur on be (4) roots, followed by atehe. There is frequent juxtaposition of the EQS 'be' $a$ - verb followed by atehe, referencing persistence of the various types of EOS stative predications such as identity, physical properties, appearance, and as in (4), kin relations.

3 The Southern Cariban morpheme feke is multifunctional, including ergative and what Franchetto calls 'perspective' use, where she glosses it PRSP, a practice I follow here and elsewhere in my examples - especially when glossing the quotative that includes this morpheme (FRANCHETTO, 2010, p. 134-138). I consider this usage a sentence-focus (thetic) strategy (LAMBRECHT, 2000). 
Here atehe follows EQS $a$ - in plural perfective (bracketed) which is followed by the main verb 'give' also in perfective inflection. (see also 8.iii for the verb e-, 'come', in nominalized imperfective construction)

(4)
u-ĩfo-gu-
a-ningo]
atehe e-iña-ni
tu-nigi
1-respect-POSS
2.EQS-PFV;PL PER 2-BEN-FUT.1 give.to-PFV

'Because you all have been my respect relatives (=affines) in the past, it's something that will be given to you soon.'

\subsection{Atehe with pronominal prefixes}

Important evidence of the verbal character of atehe is the presence of pronominal prefixes that are hosted by lexical and copular verbs. (As would occur with possessed nominals also hosting prefixes to mark possessor, atehe never hosts a possessive suffix). In several of my examples, pronominal prefixes which never occur on Kalapalo adverbs do appear on atehe thus providing some evidence for the verbal character of the perfect. Where any pronominal prefix occurs with atehe $(5,30 \mathrm{iv}, 32 \mathrm{ii}, \mathrm{iii}, \mathrm{v}$, $35 \mathrm{ii})$ it is always one of the three types of first person: the $\operatorname{singular}(28 \mathrm{ii}, \mathrm{v} ; 30 \mathrm{ii})$, the dual $(26 \mathrm{iv} ; 28)$, or the exclusive 'we' (28iii).

In (5iv), the dual plural absolutive pronominal prefix $u \boldsymbol{k}^{\mathrm{w}}$ on atehe appears to mark a copular subject; the initial de-verbal adverbialized word 'resembling (him) in our graves' appears to function as a copular complement. There is a future perfect sense as the adverb is marked with the potential future tense (FUT.2). In line iv there is also reference to an earlier situation that is given status as an experiential perfect since it concerns the death and burial of the woman's husband.

(5) i. ah e-fi-dyi ake-tsa-ne u-its-a

EXP 2-touch-PNCL SD-EX-I 1-EX-CONT

'The fact is I really want to touch (= copulate with) you.'

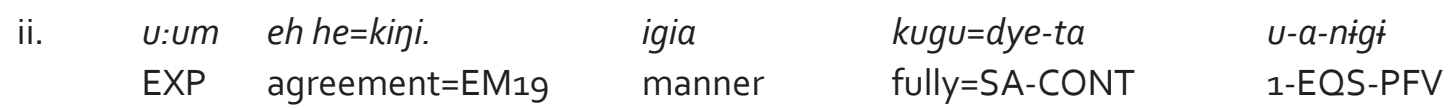

'I'm thinking I can't agree. I'm still really doing this for him" (i.e., she is in mourning, still celibate)'.

nigitifeke.

iii. afiti-dye -nigi-ti i-feke

denial-SA QUOT-EV 3-PRSP

' "No, you don't have to be that way", they say he kept answering her'.

iv. una-no-ino-finï $u k^{w-a}$ atehe.

grave-NLOC-FUT.2-resemble dual-PER

'We'll be buried like him as before sometime later on'

\subsection{Atehe and temporal morphemes.}

While there are no present or past tense markers on the Kalapalo verbal (or nominal) constructions, there are inflections belonging to the epistemic (EM) and interclausal reference (IRM) marker classes 
that lend temporal meanings to the clause. (6 ii) illustrates the epistemic marker with past semantics. See section 2.8 for IRM examples.

In (6) a young man has left home because his father has abused him. Upon arriving at his grandfather's camp along the river, he is captured by some foreigners. He agrees to leave with them and he explains to his grandfather (lines ii and iii) why he has come to him. The speaker uses wãke, EMı as a reference to first-hand experience of events occurring in the distant past (see also (28) for another example of EMı use). The ule demonstrative clause in line iii links the prior predications in lines $i$ and ii to the last imperfective clause (bracketed).

(6)

i.

aketsigei,

$\begin{array}{llllll}\text { apiči, } & \text { u-te-ta } & \text { ake-tsa } & \text { igei, u-te-lu. } & \text { eh he } \\ \text { Grandfather, } & \text { 1-go-CONT } & \text { SD-EX } & \text { IDEM } & \text { 1-go-PNCL. } & \text { agreement }\end{array}$

'Grandfather, this means I've decided (chosen\} to go away, I'm leaving'. 'All right'

ii. apa-dyu aki-si-- sine-ki wãke u-e-nigi apiči

Father-END speech-POSS pain-ADV EM1 1-come-PFV GFa

'My having come Grandfather as for a long time I experienced Father's painful speech'.

iii. high topic context: use of ule

ule atehe ku-aka igei [u-e-tifigi].

APR PER intensive-EM21 IDEM 1-come-IMP

'As you can tell, that's just why I've decided to come (= from what I've said the very reason for my decision to be a com-er)'

\subsection{Juxtaposition of anigi (pl: anino)+ atehe, 'as has/have been before'}

PER often follows the active stative 'be' verb in perfective inflection. This periphrastic construction appears to signal lingering persistence of one of EOS perfective predications, such as identity, appearance, kin relationships (7) and cognitive situations or states (8).

In (7), the temporal adverb gele, 'still' contributes to the perfect significance of the utterance.

$\begin{array}{lllll}\text { u-ifo-gu } & \text { gele-fa } & \text { ñandsu-ko-kai=lefa } & \text { u-anigi } & \text { atehe. } \\ \text { 1-respect-POSS } & \text { still-TOP } & \text { sister-PL-ALOC=SEO } & \text { 1-EOS-PFV } & \text { PER }\end{array}$

'You are still my respect relatives as I have remained with your sister as before (in the past).'

(8)
i. $\quad k u-\tilde{n} \dot{g} \dot{t}$
ti-fana-gi
ekege aki-ti-ino
fegei
'We have changed (=our changing) because the jaguar will enjoy hearing this'.
ii. Ule-pe a-nigi atehe
APR-ESS EQS-PFV PER
'That's how it became that way before (in the past).' 


\section{6 ule atehe. 'that's why'}

This common syntactic pairing links the active participant's (A/S) motivation in the prior event clause as the reason or purpose for the consequence of the situation in the subsequent (connecting or subordinate) clause. In these contexts, ule has a demonstrative noun- to-verb clause-chaining function. When clause-initial, ule references a prior strong topical element:

The following is an example in which the prior predication (the extremely hard bird's beak) is nominal.

$\begin{array}{llll}\text { i. ũ i-si-git, tu-fili-ñ-fa } & \\ \text { axe 3-tooth-POSS, REF-hard-EXN-TOP } \\ \text { 'Its tooth (i.e. beak) is its axe, its tooth is someth } \\ \text { ii. ule atehe tefu eku-tar } & \text { i-feke. } \\ \text { APR PER rock eat-CONT } & \text { 3-ERG } \\ \text { 'That's why it (the bird) was eating the rock'. }\end{array}$

Ule may also occur in periphrasis with copular clauses as in example (10).

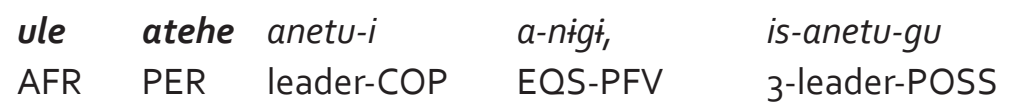

'That's why he became a leader, their leader'.

2.7. The construction ule-pe (APR-ESS); ule-pe atehe, 'that way; that's how' 'as for that'.

The demonstrative construction ule-pe (APR-ESS) points to specific physical elements of the prior situation that have consequences for the present. The essive suffix pe indicates a feature described in the prior clausal situation (e.g. 11i) as a reason or purpose for what is described in the subsequent clause. The following is an example with atehe following (in clause-final adverbial position) the nominalized transitive verb 'reject'. At the conclusion of the utterance, atehe follows the recapitulation in a ule-pe clause, meaning, 'that's (the prior topical feature as before').

(11) deverbal nominalization

$\begin{array}{lllll}\text { i. Taugi anda-gi } & \text { o-ga-tifigi-fiñe } & \text { i-feke } & \text { atehe, ule-pe } & \text { atehe } \\ \text { NAME follower-POSS reject-CAUS-IMP-EXN } & \text { 3-ERG PER } & \text { APR-ESS } & \text { PER }\end{array}$

'She's been spurning Taugi's followers as before (=she is Taugi's followers' reject-or'), that's (the sort of person she has been) as before.'

\subsection{Atehe with interclausal IRM. same/switch reference markers}

In addition to the use of APR to link clauses, Kalapalo speakers' ability to create extended narratives is enabled by the well-developed interclausal reference markers' (IRM), most distinctive to narrative discourse (Basso 2015; 2020). Most are rare or limited at best in conversational speech. A set of same/ switch reference enclitics, IRM have anaphoric and cataphoric or "anticipatory" reference. (Givón 1983) They will reference same $\left(\mathrm{SE}_{i} 12\right) /$ different $\left(\mathrm{DE}_{i} 13\right)$ past events or situations and same $(\mathrm{SA})$ or 
negative/contrastive (DA; 17i) arguments, in other words, cross- clausal continuities or discontinuities of such situations, events and arguments.

$$
\begin{aligned}
& \text { taifeke } \\
& \text { ti-iñano-i=mbe ege atehe, ta i-feke. } \\
& \text { REF-food-COP=SE PDEMN PER QUOT 3-PRSP } \\
& \text { 'Because of that food of his that is always arriving as before,' he told her }
\end{aligned}
$$

\begin{tabular}{|c|c|c|c|c|}
\hline $\begin{array}{l}\text { a-gi-no } \\
\text { 2-similar-NLOC }\end{array}$ & $\begin{array}{l}\text { atehe } \\
\text { PER }\end{array}$ & $\begin{array}{l}\text { s-agi-no } \\
\text { 3-similar-NLOC }\end{array}$ & $\begin{array}{l}\text { i-feke } \\
\text { 3-PRSP }\end{array}$ & $\begin{array}{l}\text { anetu ekugu=mba } \\
\text { leader real=DE }\end{array}$ \\
\hline
\end{tabular}

In the next example atehe follows an initial nominal 'similar'. At the end of the line, 'different event' IRM $\boldsymbol{m b a}$, DE switch references the new, different action of the referent. There is no semantic verb in the line.

'You are already just that way, already just like him a real leader'.

IRM-IRM and IRM-taxis compounds frequently occur in clause chaining, as in (14).) A speaker's use of taxis clitics contribute to temporal implications of the perfect.. (In my examples, these are lefa, SEQ sequential event; ale, UT unending or perpetual event; tale, DT different event, and the temporal adverb gele, 'still'.)

In the initial complement clause (14 $\mathrm{iii}$ ) is a speaker's use of atehe with IRM and taxis compound enclitics

\begin{tabular}{|c|c|c|c|c|c|}
\hline (14) & $\begin{array}{l}a-\eta i \\
\text { EOS-SN }\end{array}$ & $\begin{array}{l}\text { kine } \\
\text { flatb }\end{array}$ & ad & $\begin{array}{l}k u-l i \\
\text { eat-PNCL }\end{array}$ & \\
\hline & 'Here's s & some bread f & you to e & & \\
\hline ii. & $\begin{array}{l}\text { afiti } \\
\text { denial }\end{array}$ & $\begin{array}{l}\varnothing \text {-nigí-tifa } \\
\text { QUOT-EM2 }\end{array}$ & $\begin{array}{l}\text { i-feke } \\
\text { 3-PRSP }\end{array}$ & $\begin{array}{l}\text { fitsu } \\
\text { wife }\end{array}$ & $\begin{array}{l}k i-l i \\
\text { utter-PNCL }\end{array}$ \\
\hline
\end{tabular}
$m b a=$ tale marking a different future event with different future results (DRES), 'do something else so that there is a different ending'. In this line there is a continuous inflection(CONT) on the verb 'eat' that operates with the prior complement clause in line ii.

'No I won't', she corrected him, his wife spoke.

mbatale (DRES\}

iii. ah, enu=mba=tale teku-mbe-ga atehe.

EXP involve-DE=DT eat.vegetable.food-TRN-CONT PER

'The fact is from now on I'll do something else (than what you say), continue eating vegetable food as before (in the past).'

\section{9 atehe and negation.}

The perfect may occur in a negative clause marked by the initial standard negation marker (i)ñali NEG-, 'not'). The construction in (15) is NEG=EM4 ('Not X, don't know why'). 


\begin{tabular}{|c|c|c|c|}
\hline $\begin{array}{l}\overline{7} a l \dot{t}=m a \\
\text { NEG-EM }\end{array}$ & $\begin{array}{l}\text { ege-a } \\
\text { manner-U }\end{array}$ & $\begin{array}{l}e-k i-l i \\
\text { 2-utter-PNCL }\end{array}$ & $\begin{array}{l}\text { atehe } \\
\text { PER }\end{array}$ \\
\hline
\end{tabular}

'I don't know why but this is a gentle way of speaking that you never used with me before.'

A second type of negation clause may reference a contrastive meaning, as through the use of the inflection -ne on the verb which hosts CAT, the cataphoric enlitic IRM, 'do differently later' (=mbale) (16), DA, the different argument IRM dya(17), or the contrastive epistemic nipa (30).:
teku-ne-finj=mbale,
melanzia.
teku-ne-fint
topu atehe
eat-CONTR-resemble=CAT melon
eat-CONTR-resemble squash PER

'You'll see we'll no longer be eating anything (that looks) like that melon. We won't be eating anything (that looks) like his squash any longer'....

\section{Semantic distinctions of atehe usage.}

Regarding semantic implicatures, atehe as a perfect seems to have one central meaning, 'lingering relevance', namely reference to a description of a prior event or situation as an 'always' or 'already' (as before) adverb. Atehe operates in the context of a temporal relation between the past time point and one of three possible others: a) the more recent taking place yet still in the distant past; b) persisting with a continuing effect in the present; or c) that will have a connection with events in the distant future. The uses of these constructions often have a resultative meaning as marked by the ule clause with atehe that often describe deliberate goals or experiential consequences of prior actions.

Several of Comrie's (1976) functional distinctions are selected according to the semantics of Kalapalo predicated clauses that convey information about the situations or events linked by atehe. Kalapalo material also requires that I add several other functional types including constructional combinations with contrastive perfect morphemes. Accompanying these semantic perfects are the kinds of clauses and morphemes with temporal meaning. Table 1 summarizes these functional distinctions of atehe and my translations of these types. The grammatical features that are associated with each in my numbered analyzed examples are seen in the sections following the table.

Table 1: Types of Atehe Morphosemantic Functions

\begin{tabular}{|l|l|l|}
\hline Types of Functions & Examples in text & Translations \\
\hline $\begin{array}{l}\text { A. Perfect of anterior past result: } \\
\text { a present state is referred to as being the } \\
\text { result or a reason connected with some } \\
\text { past situation (COMRIE, 1976, p. 56) }\end{array}$ & $2,8 \mathrm{ii}, 10,17 \mathrm{ii}, \mathrm{iii}, \mathrm{v} ; 18 \mathrm{iii}$ & $\begin{array}{l}\text { 'that's why' } \\
\text { 'done already' }\end{array}$ \\
\hline $\begin{array}{l}\text { B. Experiential perfect: "a given situation has } \\
\text { held at least once during some time in the past } \\
\text { leading up to the present".(COMRIE, 1976, p. 58). }\end{array}$ & $\begin{array}{l}11 \text { 12, 18ii, 19iv, v 20i, ii; } \\
28 \mathrm{v} ; 29 \mathrm{ii}\end{array}$ & $\begin{array}{l}\text { 'now as before } \\
\text { in the past' }\end{array}$ \\
\hline $\begin{array}{l}\text { C. Perfect of persistent situation: " to } \\
\text { describe a situation that started in the } \\
\text { past but continues (persists) into the } \\
\text { present" (COMRIE, 1976, p. 60). }\end{array}$ & $\begin{array}{l}3,4,7,9 \mathrm{ii}, 13 \mathrm{i}, 21 \mathrm{ii} ; 22 \mathrm{iii} ; 23 \mathrm{iii} ; \\
28 \mathrm{iii}, \mathrm{iv} ; \text { 30iii }\end{array}$ & 'always', 'as always' \\
\hline
\end{tabular}




\begin{tabular}{|l|l|l|}
\hline $\begin{array}{l}\text { D. Perfect of recent past, 'hot news': "... } \\
\text { used where the present relevance of the } \\
\text { past situation referred to is simply one of } \\
\text { temporal closeness, i.e., the past situation } \\
\text { is very recent." (COMRIE, 1976, p. 60); }\end{array}$ & 6 iii, 23ii;24iii, iv; 25iii & 'just before' \\
\hline $\begin{array}{l}\text { E. perfect of recent past contrastive: the } \\
\text { negation of an experiential situation is } \\
\text { contrasted with the present situation or state. }\end{array}$ & $3,15,25 \mathrm{i}$ & $\begin{array}{l}\text { 'never (did/ used/, } \\
\text { was) until now }\end{array}$ \\
\hline $\begin{array}{l}\text { F. Perfect of potential/distant future: "the } \\
\text { situation that has occurred in the past will have } \\
\text { relevance for the future... a 'past situation } \\
\text { in the future (COMRIE, } 1976, \text { p. 64). }\end{array}$ & 5 iv,16;26iv; 28ii & $\begin{array}{l}\text { 'later on as before', } \\
\text { 'will happen as before }\end{array}$ \\
\hline $\begin{array}{l}\text { G. Perfect of contrastive potential/distant future } \\
\text { : Used when a past event that is connected } \\
\text { with a future situation is negated, or when } \\
\begin{array}{l}\text { the reference marking of the future clause } \\
\text { includes an element with future implicature. }\end{array}\end{array}$ & $13,14 \mathrm{iii,} 27 \mathrm{ii} ;$ & $\begin{array}{l}\text { 'differently later on/ } \\
\text { from now on', } \\
\text { 'no longer', 'won't do it } \\
\text { that way from now on' }\end{array}$ \\
\hline
\end{tabular}

\subsection{The perfect of anterior past result, 'due to have already happened/done $X^{\prime}$; 'that's why'}

Comrie describes the perfect of anterior past result as follows: "a present state is referred to as being the result of some past situation. This is one of the clearest manifestations of the present relevance of a past situation." (p.56). The Kalapalo perfect of past result is a consequential use of atehe with APR ule. or in some cases atehe following a full clause. This is an expression of causality that references the consequence of or relevant reason for what follows a previous situation or action. A lingering state of a prior situation thus has a continuing effect on a current event.(GIVÓN, 2001, p. 295, STASSEN, 2003). The perfect of anterior past result is common in Kalapalo narratives where causal explanations of current existential situations or states involving humans are pervasive.

(17) The following example illustrates how predicates are linked in narrative by atehe, creating segmented narrative features. There are two of these in a chain in this example. First is the frequent narrative use of the perfect of anterior past result which occurs in line ii. There, atehe follows ule-pe to reference a causal relationship between the immediately prior narrated events (line i). The subsequent consequence is described in the main clause (iv-v) following the second ule clause (iii). This second result is a description of the mythic origin of a persisting situation and perpetual lingering relevance.

Background:

tinimbifeke-

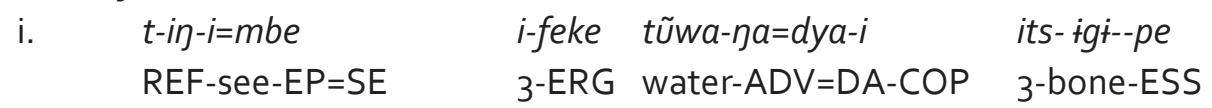

'He $\mathrm{H}_{\mathrm{i}}$ watched (what he $\mathrm{j}_{\mathrm{j}}$ was doing) his soaking those bones.

igea=lefa a-nakafu-gu-a a-tifigi tama-ki

manner=SEQ 2-hair-POSS-U EOS-IMP soft-ADV

becoming soft, what your special kind of hair is like,' 
ii. ule-pe atehe-tsi-fa

APR-ESS PER-EV-TOP

'That particular feature existing from before, what I've been talking about.'

iii. ule atehe-fa tu-tefu-andi kuk ${ }^{w}$-at-ani

APR PER-TOP REF-stomach-full 1+2-EOA-FUT.1

'That's just why, when one of us becomes pregnant'

iv. afiti kagikagi tene-lu-la kupehe

denial spiny.catfish eat-PNCL-NEG 1+2;ERG

'we don't ever eat spiny-finned catfish.'

v. ule-pe atehe-fa agafafa-feke kagikagi ene-li-

APR-ESS PER-TOP sunbittern-ERG spiny.finned catfish eat.flesh- PNCL

'As far as that's concerned, (only) sunbittern eats spiny finned catfish.'

3.2 The experiential perfect: 'as happened before in the past', 'now as before in the past'.

Comrie describes this perfect as indicating "that a given situation has held at least once during some time in the past leading up to the present"(1976, p. 58). Bybee et.al.write more specifically "certain qualities or knowledge are attributable to the agent due to past experiences' (1994, p. 62).

(18) The following chain shows a perfect experiential with a rhetorical question leading into the clause modified by the perfect construction.

Backgrounding:

mbaka

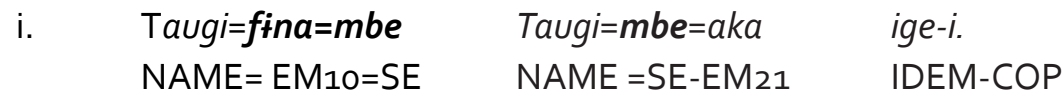

'It's possible that Taugi did it'. 'I'm sure Taugi did this.'

Perfect experiential:

ii. kwigatehe

ti-me=male ige-a kw-ii-ga atehe.

RQ-FACS=DAD IDEM-U 1+2-do-CONT PER

'But why in the past didn't he make us differently from how we are now?'

As shown in (19) [see also excerpt in (3)] the Kalapalo experiential perfect occurs with perfective (temporary, recurrent) aspect nominalizers or a perfective copular state (anïgi or the-plural anïgo ). In line (iv) the lexical verb tu-, 'give' is also inflected by a passing state perfective nominalization (PFV). Line iv describes as the reason for Jaguar's polite agreement to go along with the unreasonable request of his Frog relative in (ii). 
(19)

Backgrounding:

i. uwamigei

$\begin{array}{lllll}\text { uwa-ma } & \text { igei } & \text { u-ili-lu-iña } & \text { e-ta-ko, } & \text { uwa } \\ \text { Q-EM5 } & \text { IDEM } & \text { 1-do-PNCL-DAT } & \text { come-to CONT-PL } & \text { Q }\end{array}$

'For what have you all come to have me do, what?'

Request:

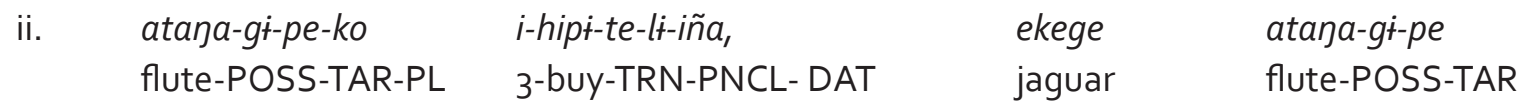

'To buy one of your flutes', the Jaguar's flute'.

Negative response:

nigifeke

iii eh he kini nigi i-feke, e-ge-tue=apa

agree EM19 QUOT 3-PRSP 2-take-I=EM27

'I can't agree', he answered him, 'Take it if that's what you want to do.'

Reason for negation (iv, v):

$\begin{array}{lllll}\text { iv. } \quad \text {-ĩfo-gu } & \text { a-ningo } & \text { atehe } & \text { e-iña-ni } & \text { tu-nigi } \\ \text { 1-respect-POSS } & \text { 2-EQS-PFV;PL PER } & \text { 2>1-BEN-FUT.1 } & \text { give.to-PFV }\end{array}$

'As you all have already been my respect relatives (=affines) before (in the past) it's something I will give you.'

$\begin{array}{lllll}\text { v. u-ĩfo-gu- } & \text { gele-fa } & \text { ñandsu-ko-kai=lefa } & \text { u-a-nigi } & \text { atehe } \\ \text { 1-respect-POSS-COP } & \text { still-TOP } & \text { sister-PL-ALOC=SEO } & \text { 1-EOS-PFV } & \text { PER }\end{array}$

'You have still chosen to be my respect relatives as I remain together with your sister as before in the past'.

3.3. The perfect of persistent situation, 'now as always (before) in the past' (atehe marks nominal clause)

I generally use the translation 'as before in the past ' or 'as always as before'. Comrie describes the use of this perfect " to describe a situation that started in the past but continues (persists) into the present" (COMRIE 1976, p. 60). This is called the 'universal perfect' by Dahl and Velupilla (2013, p. 2). In Kalapalo this perfect appears with active motion verbs such as: go, come, arrive, and do/make..

Example (20) shows atehe in a perfect of persistent situation with a non-causal explanation that contradicts the previous speaker's assertion. In line i the continuous aspect on the main verb timbe'arrive' signals this notion of a perfect of persistent situation. Line ii describes the 'present situation' event.

$$
\begin{array}{lllll}
\multicolumn{2}{l}{\text { timbegatehe }} & & & \\
\text { i. } \quad \text { ah } & \text { timbe-ga } & \text { atehe } & \text { ti-iñango } & \text { kusiugu } \\
& \text { EXP arrive-CONT PER REF-food } & \text { sweet. manioc PER }
\end{array}
$$

'Believe me, now as before in the past, that food of his arrives day by day, those sweet manioc roots...' 
In line ii, the interclausal reference marker =mbe, 'same event' references the particular 'persistent situation', the arrival of those same kinds of food that began in the past, which is described explicitly in the prior line. Atehe follows ege, the pronominal demonstrative marking the head noun of the prior clause:

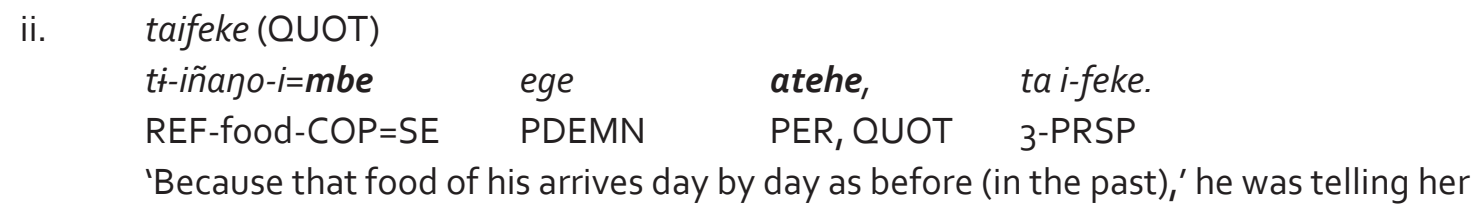

In (21) there is a current event described by means of an intransitive verb in anticipated inflection with adverbial adjunct. This is an explicit past repeated event marked with atehe on the comitative argument. Atehe occurs between this and the following relative clause which ends the line. The appearance of atehe in this place and not after a verbal phrase may indicate the speaker's interest in highlighting the fact of the woman's ugly lover, not the usual woman's early morning task of drawing water from the water's edge. (21) is a contrastive example showing atehe following the $a$ - stative equative verb which the speaker wishes to emphasize rather than the following nominal modifier.. My translation of the atehe complement 'as before' is confirmed by the speaker's use of both 'ale', the 'repeated event' taxis clitic, and the nominal suffix su, 'foolish' or 'incompetent' (acting in a kind of persistent or compulsive manner). Both of these occur on the adverbial tuwa-ka-su (hosting the unending taxis =ale, 'as usual on the way to the water, foolish/incompetent one' (bracketed).

i. $\quad$ utelaketsane nigifeke tuwakasule

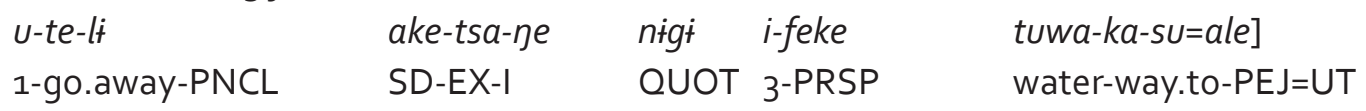

'I have to go away', he said to her on his way to the water as that disreputable person always did go'
ii. efitsu a-tani=lefa, tuwa-ka=lefa is-adyo-ake atehe fesi-ñi-ake, wife EQS-FUT.1=SEO water-way.to=SEO 3-lover-COM PER ugly-EXN-COM 'While his wife was about to be on her way to the water, to be with her lover as before in the past, now with that ugly person'

In the following example, the prior situation (line iii) is given as a reason after Agutsini's refusal. The prior situation, which is relevant to the event located 'now' (Bybee et.al.1994: 62), does not imply completion as there is no perfective inflection. feke in this example is glossed PRSP, 'perspective' as it is marking the $\mathrm{O}$ quotative argument. Because in ( $22 \mathrm{iii)}$ ) the clause is negated with the negative marker ñali, my atehe translation 'never as before' seems appropriate. .

(22) i. nigifeke Imperative backgrounding

agutsini, nigi i-feke, tis-otu e-nu-ne

NAME OUOT 3-PRSP, 1+3-food 2-give-I

'Agutsini', they said to him, 'Give us our food'. 
$\begin{array}{llll}\text { ii. otu-ko } & \text { a-tu-nali } & \text { u-feke } & \text { Questioned response } \\ \text { food-PL } & \text { 2-give-REV } \quad \text { 1-ERG }\end{array}$

Negation background response

iii. ñali-ma o-wi-ko te-lit atehe [otu-ko ufi-dyu-iña]

NEG-EM5 2-father-PL go.away-PNCL PER food-PL find-PNCL-DAT

'I don't think now as never before (in the past) your father went away to look for your food.'

In the next example, atehe occurs in a narrative sequence illustrating the perfect of a persistent situation as ' a beautiful thing that comes up quickly'. This is a repeated punctual event that is described both with lexical verbs and ideophones. In line ii atehe follows 'quickly', the topically marked adverb, . initiating the strong focus perfect of anterior past result of ule in line (iii). where atehe again complements ule. Line iii describes the consequence of the prior event, the lexical verb indicating 'repeatedly pulling out a plant by its roots', with a final ideophone that describes the event of the grass coming out readily.

(23) i. ige-na $\quad \varnothing$-iño-ki-pigi i-ip-ofo-ino ati-ga fegei

IDEM-SN 3-pull.out-TRN-PERF. 3-sprout-USIN-FUT.2 grow.up-CONT ADEM

'When this kind of thing has been pulled out, new sproutings will later grow up from them.'

ii. teh heh heh! agetsiki-fa atehe.

very nice! (ideophone) quickly-TOP PER

'Teh heh heh ! It appears very nicely as before (in the past)'.

Persistent consequence:

iii. ule atehe i-ño-ki-li-ti i-feke, tiditïidi

APR EQS-PER 3-pull-TRN-PNCL-DES 3-ERG, (ideophone: coming out of the ground)

'That's why, from now on when someone wants to pull it out, tïdi, tïdï(=it comes out readily).'

\subsection{Perfect of recent past, "as just before (in the recent past); already just now'.}

Comrie writes, 'used where the present relevance of the past situation referred to is simply one of temporal closeness, i.e, the past situation is very recent' (1976, p. 60).

In the following narrative example, the narrator's use of the nominal voluntary perfective aspect (VPE) suffix on the head noun (lines iii and iv) is followed by the atehe complement expressing the perfect of recent past. This perfect contrast is reinforced by the narrator's use in line iv of the 'habitual' suffix on the verb root e-'come.to'. There is an epistemic contrast regarding this perfect involving two sisters with regard to the husband of the oldest (disguised by his grandfather with a repulsive skin of sores, the oldest sister rejects him totally). This perfect of recent past is reinforced by the narrator's use of the 'habitual' suffix on the verb root e-'come.to' (line iv). 
Backgrounding conversation:

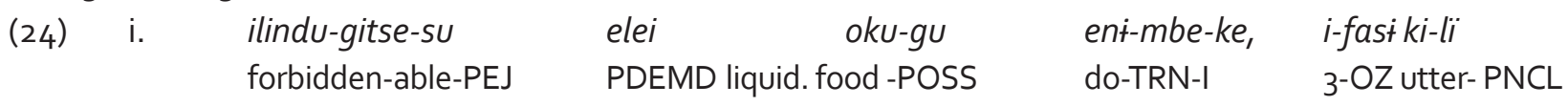

'You're forbidden to prepare that unsuitable person's porridge', her older sister said'.

ii. nigifeke

ah la-tsit, $\quad \varnothing$-nigt

EXP OUOT 3-PRSP fully come.to-PFV=SA-EV 1-ERG

'The fact is, I've been telling you that's really what happened', she answered, 'I'm telling you I've done everything for him.'

Line iii provides the reason for information provided in line (ii); atehe follows a de-verbal nominalization, 'his having been seen':

iii. i-ni-pigi atehe i-feke tuwa-ka-ga.

3-see-VPE PER 3-ERG water-way.to-ADV

'Just before, she had seen him (= his having been already seen by her) on the way to the water.'

iv. teh i-ni-pigi atehe i-fasi-iña kaah si-ta=tiga

EXP 3-see-VPE PER 3-OZ-DAT FRUST 3-come.to-CONT=HAB

'Just before she had seen him (= his having already been seen by her) how really nice he was even though he disappointed her older sister every time he came to her'.

\subsection{Perfect of recent past contrastive, 'never did/was used'in the past as now'}

In this type of perfect, the negation of a recent situation is contrasted with the present situation or state, often with an evidential-like quotative use of the verb ki, 'utter'. In (25i) a conversation begins with the husband arguing with his wife; the negated past experiential situation clause is marked by atehe while the preposed negative hosts the 'unknowing' epistemic clitic: ñalï=ma, 'not in my experience'. The wife answers in line (ii), and the husband replies in line iii. The latter response (a perfect of recent past) also shows the interesting connection between the de-adverbial nominalizing locative no, NLOC 'right there' and the idea of immediacy and exactness: 'just so', 'perfectly'. (Note the multifunctional use of feke as PRSP to mark $O$ in lines i and ii, and as ERG to mark $A$ in line ii.)

Husband speaks:

\begin{tabular}{|c|c|c|c|c|}
\hline $\begin{array}{l}\text { i. ñali-ma } \\
\text { NEG-EM4 }\end{array}$ & $\begin{array}{l}\text { egea } \\
\text { manner }\end{array}$ & $\begin{array}{l}e-k i-l i \\
\text { 2-utter-PNCL }\end{array}$ & $\begin{array}{l}\text { atehe } \\
\text { PER }\end{array}$ & $\begin{array}{l}\text { atutu-ki } \\
\text { slow-ADV }\end{array}$ \\
\hline
\end{tabular}

'I don't remember if you ever spoke gently like this with me before in the past.'

Wife's criticism:

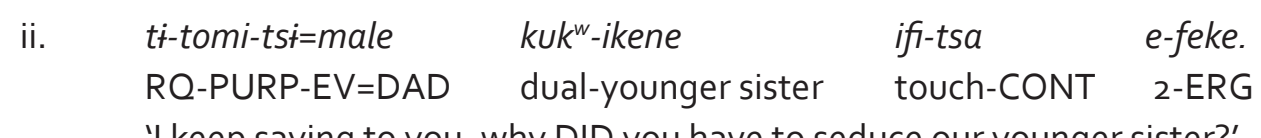

'I keep saying to you, why DID you have to seduce our younger sister?' 
Husband's reply:

iii. e-ki-li atehe atiti-ki-no-ki u-feke.

2-utter-PNCL PER low-ADV-NLOC-NMIR 1-PRSP

'I'm surprised that just before you spoke so gently to me about her.'

\subsection{Perfect of the potential/distant future, 'later as before in the past'.}

Comrie describes this as "the situation that has occurred in the past will have relevance for the future...a 'past situation in the future". (COMRIE, 1976, p. 64). This perfect is used when the situation that has occurred in the past will have relevance for the future, when a past situation is linked to a potential or uncertain future situation or event that will occur 'sometime'. The potential, usually unplanned- for future (-ino, FUT.2) will occur with most uses of this type of perfect. While the perfect is defined as retrospective with reference to a situation at an earlier time, Comrie $(1976$, p. 64) writes of a prospective meaning where "a state is related to some subsequent situation, for instance where someone is in a state of being about to do something" (this would conform to FUT.1 in Kalapalo). There is also an implied future perfect marked with a DE (different event) or CAT (cataphoric event) interclausal referent marker; see (17).

In (26) the narrator is using atehe (with a $1+2$ prefix) to contribute to a man's argument (line iii) that differs from that of the woman (in mourning for her husband) who is refusing him. Her negation in line ii does not include negative morphemes but she uses the epistemic marker EM1g which is a rejection of the man's proposition (saying the equivalent of. 'Unfortunately that's so', or, 'I can't agree'). The atehe construction is a copula adjunct following a nominalized verb. There is a future perfect sense as the noun in line (iv) is marked with the potential future tense (FUT.2). Also in line iv there is reference to an earlier situation that is given status as a perfect of past result since it concerns the death and burial of the woman's husband.

(26) Backgrounding request

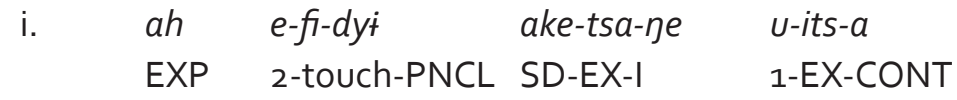

'The fact is I really want to touch (=have sex with) you.'

Her rejection

ii. u:um ehhe=kini. igia kugu=dye-ta u-a-nigi

EXP agreement=EM19 manner fully=SA-CONT 1-EOS-PFV

'I'm thinking I can't agree. I'm still really doing this for him' (i.e., she is in mourning, still celibate).

His rebuttal

nigitifeke

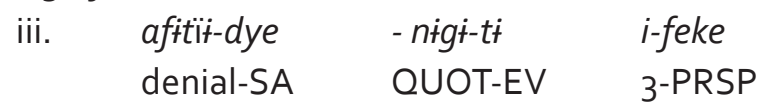

"No, you don't have to be that way', they say he kept answering her'. 
Rebuttal explained

iv. una-no-ino-finit $u k^{\text {w- }}$ atehe.

grave-NLOC-FUT.2-resemble dual-PER

'We'll both be buried like him sometime later on.

3.7 Perfect of contrastive potential/distant future, 'later on $X$ won't do it that way', 'later on $X$ will do it differently'.

This perfect is used when a proposed event that is connected with a future situation is negated or contradicted, and/or when the reference marking of the future clause includes a cataphoric element (SE.CAT or DRES). In the followiing narrative segment, the context is a dispute about travelling. A foreigner insists upon travelling in a certain direction, even though locals repeatedly show him (by hand gestures) the CORRECT direction.

Didactic assertion:

i. nigifeke

ila u-te-ta nigi i-feke, ila u-te-ta u-etu-na

far.place 1-go-CONT, QUOT 3-PRSP far.place 1-go-CONT 1-settlement- ALL

'I'm going over that way, he said (to them), I'm going over that way to my settlement.'

Response:

The future situation is marked in line ii by the IRM SE.CAT mbembale, 'different future consequence'. There is no negative morpheme here but the response in line iv includes the epistemic contradiction morpheme nipa, 'except that'; 'but if', EM 24.

\begin{tabular}{|c|c|c|c|}
\hline $\begin{array}{l}\text { opt }=m b e ! \\
\mathrm{EXP}=\mathrm{SE} .\end{array}$ & $\begin{array}{l}\text { la }=\text { mbe }=\text { mbale } \\
\text { over there }=S E=C A T\end{array}$ & $\begin{array}{l}\text { kagaifa } \\
\text { non.Indians }\end{array}$ & $\begin{array}{l}\text { a-nigi } \\
\text { EOS-PFV }\end{array}$ \\
\hline
\end{tabular}

'That's too far! If you were to (go) otherwise in that other direction, that's where the non-Indians have already been up to now (as before in the past)'.

iii. afiti, la u-te-ta-ni....

denial, distant.place 1-go-CONT-FUT.1

'But I won't, I'll be going that (other) way'...'

$\begin{array}{lllll}\text { iv. la=nipa } & \text { e-te-ke, } & \text { Atatsinu-kai=nipa } & \text { e-te-ke, } & \text { la } \\ \text { distant.place=EM24 } & \text { 2-go-IMP } & \text { NAME DEST=EM24 } & \text { 2-go-IMP } & \text { distant.place }\end{array}$

' 'Except that's the way you should go ( not what you said/want to do), you should go on the Atatsinu, way over that way'.' 


\section{Anetu itagiñu, hereditary leaders' talk: Atehe in stance-construction and boundary marking.}

In this section I give examples of anetu itagiñu, the hereditary leader's talk that is an important feature of ceremonial gatherings involving leaders of both host and guest communities. The leaders' talk includes descriptions of leaders relating ancestors of the distant past to the speaker and other participants in the current event. These poetic oratorical forms are taught by elders to their younger heirs, who must memorize the texts. The overall style of leader's talk is quite distinct as a formal register, including considerable repetition of multiple lines, pervasive phonological and morphological parallelism, a distinct intonational contouring using extended vowels ${ }^{4}$ special vocabulary including names of leaders from the distant past, the epistemic marker referencing the speaker's knowledge of the distant past (wãke, EM1) and several 'humbling' and 'counter-factual' epistemic and affective markers (BASSO, 2009, p. 253-262). A leader's ritual communication is often filled with this ironic restraint, a kind of respectful devaluation of the work of his own messengers. There is a feeling of the speaker's modesty enacted by his disclaimer.

Franchetto first published written descriptions of this ritual genre (1983), stating that 'It stands for something that has always existed and thus fosters a sense of continuity between myth and Xingu ceremonial activity." (However, while atehe occurs in a number of lines in the texts I have elicited from Kalapalo leaders, I do not see atehe in any of the Kuikuro texts of leader's talk published by Franchetto (1983; 2000; in 2019 p.c. she asserts atehe does not occur in Kuikuro ). There is an unglossed Kalapalo text in Guerreiro 2015:95, and some other Alto Xingu Southern Cariban texts collected by the same author (2015, p. 330-332,vp. 336-337) where atehe appears.

Example (28) is taken from a speech by the late leader Kambe which I elicited and recorded in 1979. In these he used the persistent perfect repeatedly. The following section of his text concerns the arrival of ceremonial messengers who are greeted by the leader of the guest community. The leader's emphasis on conformity of current practice with that of the distant past is important, and the leader's own status is marked by his competent use of the ceremonial register. The use in lines iv and $v$ of the epistemic particle wãke (EM1) references distant past time although it is not an explicit past tense marker. In line (i), atehe occurs between the active intransitive verb in PNCL inflection and the final adverb 'still'.

$\begin{array}{lllll}\text { (28) i. } & \text { ti-kaina-fint=mana } & \varnothing \text {-atsa-ki-li } & \text { atehe gele-fa } & \text { wãke } \\ \text { RQ-DEST-resemble=EM5 } & \text { 3-run-ITR-PNCL } & \text { PER still-TOP } & \text { EM1 }\end{array}$

'Why can't I think that like the others he runs to the same place (as they had done from then until now)?'

$\begin{array}{llll}\text { ii. } & \text { e-i-ta-ino } & \text { tu-e-mbu-kilt } & \text { enoku } \\ \text { 2-come-CONT-FUT.2 } & \text { 1-PER } & \text { REF-arrive-ITR-NADV } & \text { messenger } \\ \text { 'Messenger, you will come sometime later as I always did before, not yet your own arrival'. }\end{array}$

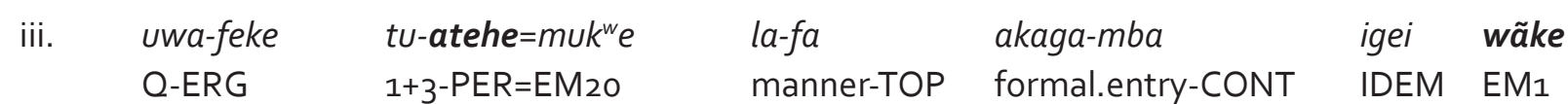

'Why do we others always enter formally like that now as in the distant past?'

4 In all examples of a leader's talk, extended vowels are shown doubling. 


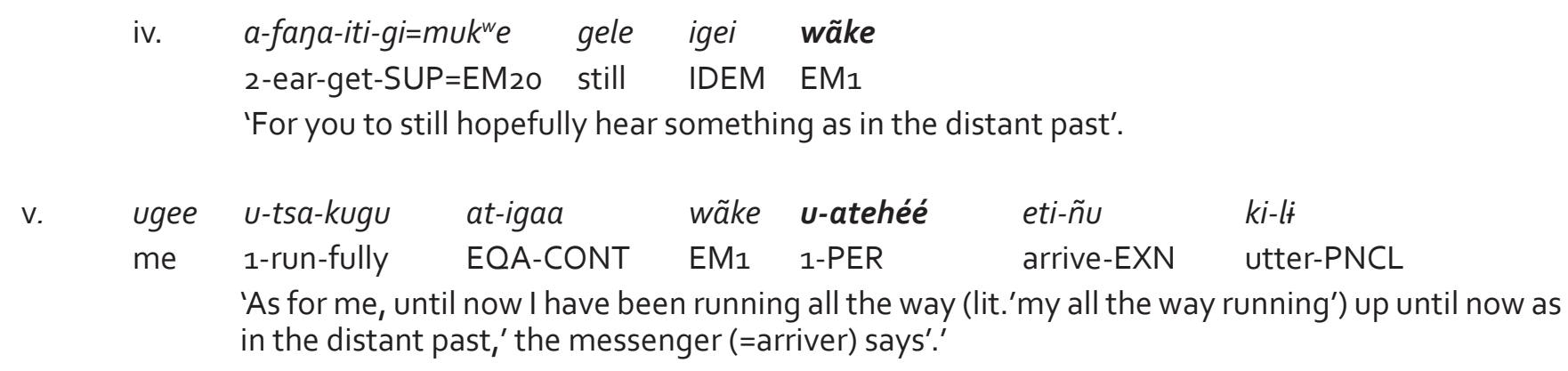

Example (29) is taken from Ageu's elicited leader's talk recorded in 1998 at Aifa settlement. This speech by Kambe's oldest son also concerns the arrival of ceremonial messengers from a host community. In this segment the fact of hereditary leaders arriving for the ceremonial celebration is downgraded by the host speaker, an important and characteristic expression of humility and personal modesty on the part of hereditary leaders (confirmed by Guerreiro's 2017 analysis). Politeness speech is marked with $m u k^{w} e, E M 20$, 'hope (perhaps in vain)':

(29) ukanambagitse

i. ah inde-ne $=m^{w} k^{w}$ ila u-kana-mba agitse

EXP here-OP=EM20 manner 1-formal.entry-DE able

'Surely hopefully not in vain here like that, able to make my formal entry'.

ii. ukw-a-nigi-ko atehe $=m u k^{w} e$ ila agitse

1+2-EQS-PFV-PL PER=EM20 manner able

'As not in vain we always hoped for in the past, able that way (now).'

Finally I use a third example from Ageu's recording in 1998, which involves a ceremonial conversation between the leaders and the messengers. The messengers have returned and are greeted by the leader. This section describes the greeting and response of the messengers, describing their 'always running all the way'. The gifts of shell ornaments and valuable feather ornaments are used to mark the commitment of the greeting leaders to the ceremonial arrangements that will follow. The messengers are in principle themselves younger hereditary leaders, who have already learned the ceremonial speeches. When the guest leaders eventually arrive, these younger messengers are responsible for escorting them around the community to receive greetings and gifts from other household leaders, and for seeing the visitors are properly fed.

i. Greeting by the leader to the arriving messenger:

ninoku ninoku ninokuu its-inaa, e-timbe-ga-tigaa

messenger messenger messenger EX-SN 2-arrive-CONT-HAB

'It's the messenger messenger messenger, you are arriving as usual'

ii. The messenger's response to the greeting by his leader:

$\begin{array}{lllll}\text { ugee } & \text { u-tsa-kugu } & \text { a-ti-gaa } & \text { a-gino-feke } & \text { wãke u-atehéé } \\ \text { me } & \text { I run-full } & \text { EOS-HAB } & \text { 2-resemble-ERG } & \text { EM1 1-PER }\end{array}$

'As for me, all my running (=my running all the way) me like you always in the distant past.' 
iii. The leader's response; only the first of several repeated lines is shown:

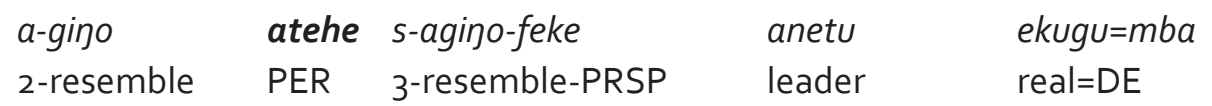

'You are like he was before.' (=he behaves like the real leader did before)

\section{Conclusions and topics for further research}

As seen in this essa examples, there are a large number of nominal and verbal clausal types associated with the use of atehe. In the speech of the Kalapalo users, atehe manifest many of the grams shared by both verbs and nouns and some adverbs in Southern Cariban languages (FRANCHETTO, 2008; 2010; BASSO, 2020). Atehe is a free form with its own syntactic, semantic and pragmatic functions. While uses of pronominal prefixes with atehe suggest a verbal function, the larger number of uninflected atehe uses suggest that this Kalapalo adverbialization has moved away from copular verbalization, adopting the functions of other unbounded postposed adverbs. "As before (in the past)" is used as my translation in such syntactic settings, but also "as always before" if there is a repeated taxis clitic on the verb; and "later on" when a future marked clause occurs.

Atehe is syntactically distinct from, but apparently grammatically related to the few inflected suffix perfects described for Northern Cariban languages (CARLIN, 2004; PAYNE; PAYNE, 2013). As Dahl and Velupilla note, it is not unusual that "a perfect may be employed in functions similar to those of inflections" (2013, p.2). Syntactically atehe also appears in positions identical to those of Kalapalo 'be' verb inflections, that is, following a NP copular complement, and like those 'be' verbs, may be inflected with a pronominal prefix and a restricted number of nominal, verbal and adverbial suffixes (no possessives allowed). These features suggest that in those cases at least atehe was still being used at the time of my research (late-mid $20^{\text {th }}$ century) as an inflected copular verb.

The apparently unique presence of atehe in narrative and ritual speech, and in quoted conversations, may be the consequence of the particular conservative value placed upon the highly valued genres in which it occurs, and also the need (at least at the time of my research) that older speakers had to assert the relevance of ancient discourse practices such as narratives and leader's talk to then-current social situations in the Alto Xingu. This is an important example of Givón's discussion of the semantics of the perfect (2001, p. 293-296), regarding lingering relevance and the lack of temporal boundary. There are also some instances of evidential implicatures connected with references to the distant past. This leads me to infer that, as Paul Koskrity argues, ethnopragmatic and language ideological factors need to be understood regarding speakers' grammatical reanalysis that has led to grammatical renovation. (2010: 91).

Concerning levels of changing semantic relations involving atehe, Kalapalo shows a mixed picture. As I have shown, Kalapalo syntactic functions vary where atehe is included. In a simple clause with a lexical verb having only one argument, atehe acts as an adverbial postposition. If there is no verb but an interclausal reference marker on the nominal head, atehe follows the demonstrative referencing the head which is foregrounded in the line. Where there is a subordinate clause, atehe is still functioning as a perfect with the main verb, appearing between the two clauses, or it may occur after the argument of the main verb to create emphasis. Elsewhere atehe operates as a temporal adverbial adjunct, sometimes with evidential implicature. Atehe is also frequently the predicate in contexts where a change of focus 
is marked by the anaphoric topic referent/demonstrative ule, 'that, as just described'; in initial clausal position. When the line begins with ule it is following a series of clause chains describing prior events . As Kalapalo does not mark past tense, atehe is exploited by speakers when they are making temporal references linking a prior and subsequent event or situation. The prior event may have taken place in the distant past when it was connected to another past event; it may persist and have a continuing effect in the present, or is connected with (or within) a future situation.

Bybee et. al. (1994) write that anteriors ( such as Kalapalo) with more than one use are 'semantically older' than a set with only one semantic use. The existence of two Kalapalo periphrastic perfect constructions (ule atehe; anigi at(ehe the first of which is anaphoric, the second resultative) can be taken as a sign of a relatively 'young' Kalapalo anterior. On the other hand, atehe might be understood as an inflected copula verb form paralleling the number of other $a$-verbal constructions (see Appendix 2). If so, the fact of grammaticalization contributes to the view of a more developed or 'older' anterior according to Bybee et. al. (1994, p. 80). Connected with this idea are the types of syntactic relations and verbal and nominal predications. The very large number of enclitics - some compounded- in second position in the Kalapalo clause, seems to be another relevant model for word order patterning both in the case of the two periphrastic constructions, and where atehe appears between main and subordinate clauses. Third, the appearance of atehe as a topical or section initiating or concluding boundary marker in Kalapalo leaders' talk may represent an important reason for the apparent shift towards an adverbial function and away from copularity.

While Kalapalo negation is marked in some instances with standard negative morphemes, certain interclausal reference marking enclitics (some compounded) operate with atehe to construct contrastive or negative constructions as well as those referencing future events or situations. Also in combination with IRM involved in clausal coordination, and certain epistemic enclitics hosted by event or situation predications, the Kalapalo perfect is frequently present in narrators' descriptions of the stances of participants involving decisions or commitments. The perfect in this language not only links situations in time, but when appearing as a pronominally-prefixed (or pronominal demonstrative + atehe) construction, links participants in these different time points with regard to referenced epistemic stances and ethics.

Kalapalo perfect functionality as well as the relation between the perfect and aspectual marking is complicated by the variety of both perfective and imperfective (as well as future) verbal and nominal clauses marked by atehe. In this regard, Kalapalo material does not always support Stassen's claim that in general "...the perfect encodes a prominent interpretation of a situation in which an event is (always) viewed as completed" (2003, p. 256). Kalapalo perfects are often connecting imperfective and other non-perfective descriptions of past situations to other time points. I agree with Stassen when he writes, "Depending on whether saliency is projected on the previous event or on the resulting state, we can distinguish between a RESULTATIVE and a CURRENT-RELEVANCE interpretation of the perfect" (2003, p. 256; author's original capitals). As noted in discussion of the examples where ule appears followed by atehe, there can be such a contrast between occasions when Kalapalo speakers do not follow up the resultative with a comment about current relevance. The syntactic pairing of ule and ulepe with atehe in numerous examples conveys the semantic function of reason for a consequence. The other of the two pairings, anïgï atehe, (involving the stative equative copula verb $a$ - in passing state perfective inflection) appears to signal lingering relevance over time of the various EOS perfective 
predications, such as the character of thatching grass(23), a person's leadership identity(28-30), and the kin connection between Frog and Jaguar (19).

Kalapalo data show a few examples of the juxtaposition of atehe with several types of verbal clauses expressing futurity. These clauses include some predicated verbs inflected with the suffix-ino 'potential' or 'indefinite' future (FUT.2), and in other cases interclausal reference 'different event' marking clitics. While leaders' ceremonial talk appears to necessitate the use of atehe (occurring in all of my examples), narrative discourse has a much lower percentage of use (13-14\% of my total genre examples). From the semantic contexts of these, I infer the percentage difference concerns thematic matters in the two genres regarding the causal relations between past and current or future situations and social roles. The variation in types of clauses and predications involved with atehe use have not been subjected to statistical analysis to indicate the numbers and significance of these in the data. This is another subject for further work.

Not all texts in my extensive collection of Kalapalo narratives and chiefly discourse show a speaker's use of atehe. Some narrators never used atehe, and it is not clear if this represents language change, something to do with narrative competence, or another factor such as upbringing. Speakers who were younger than 40 or so at the time of my earlier research and have used atehe, frequently learned directly from their skilled elders, suggesting this morpheme was acquired under the somewhat special circumstances of their youth, when they were encouraged to learn ritual language. In Kalapalo, the perfect also entails a powerful pragmatic effect that certain speakers benefit from personally, involving a decision or commitment based upon access to ritual knowledge. In ceremonial discourses, the predicational uses of atehe enable a description of hereditary leaders as heirs to a personally experienced tradition of considerable relevance perhaps for some even the present, as Franchetto noted in her early descriptions of leader's talk. Contemporary leaders at the time of my research often described themselves as only 'little' leaders (intsoño anetu) rather than direct descendants of the 'full' (ekugu) leaders of the distant past, whose real heirs died from colonialist slaving and epidemic diseases. Yet through their polite and well- informed 'leader's talk' and the related ceremonial practices focused on leader's life-cycle events, these men were expected to manifest the ethical character of the distant past leadership. Still, the spoken epistemic layer of 'remembering the distant past as 'impossible' to truly replicate, and the speakers' own personal modesty and humility, referencing their own conduct as 'perhaps in vain'; and sometimes 'not possible', actually validates any particular ceremonial event in which these speeches must still occur. In this regard, atehe plays an important role in the accompanying discursive emergence of that process.

\section{Acknowledgments}

I am grateful to Joan Bybee for her generous comments and suggestions on an earlier draft. I also greatly appreciate the detailed comments by an anonymous reader, who was able to provide useful advice for improvement of my discussion of this Kalapalo material. Since 1966 my research has been supported by grants from the National Science Foundation, the Wenner-Gren Foundation for Anthropological Research, Inc., the John Simon Guggenheim Foundation, and the University of Arizona. Special thanks go to Dr. Bruna Franchetto of the Department of Anthropology, Museo Nacional, Federal University of Rio de Janeiro, whose linguistic work on Kuikuro I have clearly built upon in this and other papers on Kalapalo. My invitation to participate in the Symposium for American Indian Languages in celebration 
of the $40^{\text {th }}$ anniversary of the American Indian Language Development Institute enabled the present project to receive critical suggestions from several scholars and especially from Professor Patience Epps, University ofTexas. Of course I take full responsibility for all errors, mistakes and omissions. Above all, I wish to express my unending gratitude to three generations of Aifa and Tanguro communities in the Alto Xingu. As always I acknowledge their having continued to allow me to learn from them in so many different and lasting ways. All examples are taken from my 1966-1998 field notes and recordings made with the help of hereditary and ritual leaders. These are held together with my recent grammar of Kalapalo (Basso 2020) in the Archives of Indigenous Languages of Latin America, University of Texas, Austin.

\section{Abbreviations}

I use the standard IPA conventions with the following exceptions: Consonants: $d y\left[d^{y}\right]$, mb [mb], G(voiced

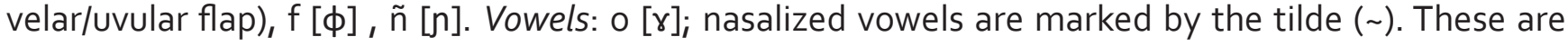
nasalized when the syllable is stressed.

\section{Non-Leipzig Glosses}

In addition to the standard Leipzig conventions, glosses used in this paper are: ADEM: adnominal demonstrative; ADV: adverbializer; APR: anaphoric predicate referent ; ALL: allative; ALOC: adverbial locative; BEN: benefactive; CAT: cataphoric; COM: comitative; CONS: consequential; CONT: continuative; CONTR: contrastive nominal; COP: class inclusion copula; DA:different actor; DAD: different adversative; DAT: dative; DERG: de-ergative; DE: different event; DEST: destination; DRES: different result; DS: deontic subject; DT: different or contrastive taxis; EM: epistemics (numbers and meanings of examples are shown in the appendix); END: endearment; EP: epenthentic; EQA: active equative; EOS: stative equative; ERG: ergative; ESS: essive; EV: evidential; EX: existential; EXN: experiencer nominalizer; EXP: epistemic expletive: FACS: facsimile; FRUST: frustrative; FUT.1: anticipative/ near future; FUT.2: potential future; HAB: habitual; I: imperative; IDEM: identificational demonstrative; IMP: imperfective; INT: intensive; IPE: involuntary nominal perfective; ITR: intransitive; IVE: involuntary result nominal perfective; MV: middle voice; NADV: negative adverbializer; NEG: negation; NEGN:negative nominalizer; NLOC: locative nominalization; NO: new overlapping taxis OP: oppositive; OZ: older sister; PDEMD: distant pronominal demonstrative; PDEMN: near pronominal demonstrative; PEJ: pejorative/mistaken; PER: perfect ; PFV: perfective nominalizer; PL: plural; PNCL: punctual; POSS: possessive; PRSP: perspective; PURP: purposive; Q; question; REF reflexive; REV: reversative; RQ: rhetorical (tag) question; RT: repeated taxis; SA: same actor; SD: deontic subject; SE: same event; SE.SA: same event, same actor; SE.CAT: same event, future consequence; SEO: sequential taxis; SN: stative subject nominalizer; SUP: supine; TAR: target; TOP: topic; TRN: transitive; U: unique; USIN: usitative; UT: unending/ perpetual taxis; VPE voluntary result nominal perfective; YBR: younger brother; $\varnothing$ : zero morpheme; ' $;$ ' portmanteau glosses (fused morpheme); $1+2$ : first person inclusive; 1+3: first person exclusive; '>':A operating on $\mathrm{P}_{i}=$ : cliticization; ','slight pause $;$ !: emphasis 


\section{Appendix 1: Epistemic morphemes in examples}

\begin{tabular}{|c|c|c|}
\hline & Gloss & Semantic features \\
\hline \multicolumn{3}{|c|}{ I. Focus on object, speaker is inside the description of object or is foregrounded } \\
\hline wãke & $\mathrm{EM}_{1}$ & Assertion about distant past \\
\hline tifa & $\mathrm{EM} 2$ & Correction of $2 \mathrm{P}$ \\
\hline nika & $\mathrm{EM}_{3}$ & Probability of $1 \mathrm{P}$ or $2 \mathrm{P}$ knowledge \\
\hline$m a$ & $\mathrm{EM}_{4}$ & $\begin{array}{l}\text { Knowledge lacking, } \\
\text { Uncertainty; hosted by } \mathrm{Q} \text { word or adverbial }\end{array}$ \\
\hline mana & $\mathrm{EM}_{5}$ & Incredulity \\
\hline fina & EM10 & Possible but weak \\
\hline$k o(h)$ & EM11 & Knowledge lacking; grammatical word \\
\hline \multicolumn{3}{|c|}{ II. Contraspective } \\
\hline kini & EM19 & Regretful, but accepting proposition (polite) \\
\hline$m u k^{w} e$ & $\mathrm{EM} 2 \mathrm{O}$ & $\begin{array}{l}\text { Positive (hopeful, wishful) } \\
\text { perhaps not in vain (polite) }\end{array}$ \\
\hline nipa & EM 24 & Contradictory: 'Except that', 'but if' \\
\hline \multicolumn{3}{|c|}{ III. Intersubjectivity: Alignments; appeals to another with grades of confidence. } \\
\hline aka: & $\mathrm{EM} 21$ & $\begin{array}{l}\text { Asserted, indicative non-past } \\
\text { existing positive alignment }\end{array}$ \\
\hline apa: & EM27 & shared goal; 'if you want to' \\
\hline
\end{tabular}

*There are 28 items in the complete paradigm. 


\section{Appendix 2. Inflectional and derivational 'be' root paradigms}

\begin{tabular}{|c|c|c|c|}
\hline & $\begin{array}{l}\text { at }(a) \text { - } \\
\text { active equative 'do', } \\
\text { 'act as', 'reach', } \\
\text { 'move to', 'enter into a } \\
\text { situation or activity'"' }\end{array}$ & $\begin{array}{l}\text { a- } \\
\text { stative equative } \\
\text { 'be as' } \\
\text { 'enter into a state } \\
\text { or condition' }\end{array}$ & $\begin{array}{l}i(t s)- \\
\text { existential } \\
\text { 'live, exist' }\end{array}$ \\
\hline Gloss & EQA & EQS & EX \\
\hline $\begin{array}{l}\text { Indicative } \\
\text { (plural:-ni;ko for intransitive) }\end{array}$ & $\begin{array}{l}\text { ata-li(-ni) } \\
\text { punctual }\end{array}$ & & $\begin{array}{l}\text { its-a(-ni; ko) } \\
\text { continuative }\end{array}$ \\
\hline $\begin{array}{l}\text { Anticipated/inchoative; near } \\
\text { future (FUT.1) } \\
\text { (plural -ni) }\end{array}$ & $\begin{array}{l}\text { ata-ni-(-ni); } \\
\text { ata-ni-ni (pl) }\end{array}$ & & its-ani(-ni) \\
\hline Hypothetical & & & its-oli \\
\hline Subordinate: purposive & & & $\begin{array}{l}\text { its--o(ko)mi } \\
\text { (ko=plural) }\end{array}$ \\
\hline Nominalization: consequential & & a-nimi & its-animi \\
\hline Nominalization: perfective & ata-nigi & a-nigit & \\
\hline $\begin{array}{l}\text { Nominalization: imperfective } \\
\text { ('not yet achieved') }\end{array}$ & & a-tifigt? & $\begin{array}{l}\text { its-ifigï } \\
\text { plural: } \\
\text { its-ifigi-ko }\end{array}$ \\
\hline $\begin{array}{l}\text { Nominalization: } \\
\text { change of state }\end{array}$ & & & $\begin{array}{l}i-\tilde{n} \dot{t g} \dot{t} \\
\text { plural:iñt-ngo }\end{array}$ \\
\hline $\begin{array}{l}\text { Nominalization: end result } \\
\text { of voluntary action }\end{array}$ & & a-pigt & \\
\hline Nominalization: attribute & & $a$-tana & its-ina \\
\hline nominalization of result & & $a-\eta і$ & \\
\hline $\begin{array}{l}\text { adverbialization: of veracity: } \\
\text { 'known'; 'current', 'recently' } \\
\text { not temporally remote }\end{array}$ & & $a$-nolo & $\begin{array}{l}\text { i-la-no 'live, be } \\
\text { recently'(?) }\end{array}$ \\
\hline Denial adverbialization & & $a-f i t \dot{t}$ & \\
\hline Desiderative adverbialization & ata-ti & $a-t i-t i$ & itsa-ti \\
\hline $\begin{array}{l}\text { Thetic (note there is } \\
\text { no thetic prefix) }\end{array}$ & & $a-t i$ & \\
\hline Perfect aspect & & a-tehe & \\
\hline imperative & & & itsa-ne \\
\hline Urgent imperative & & & its-ue; \\
\hline
\end{tabular}




\section{References}

ALLAN, Keith. Concise Encyclopedia of Semantics. Oxford: Elsevier, 2009.

BASSO, Ellen B. The Kalapalo affinal civility register. Journal of Linguistic Anthroplogy v. 17, n. 2, p. 161183, 2007.

BASSO, Ellen B. Civility and deception in two Kalapalo ritual forms. In SENFT, Gunter; BASSO, Ellen B. (Eds.). Ritual Communication. Oxford, New York: Berg, 2009, pp.243-270.

BASSO, Ellen B. Compounding in Kalapalo, a Southern Language. In DANIELSEN, Swintha et alli (eds.). Word Formation in South American Languages. Amsterdam/Philadelphia: John Benjamins, 2014, pp. 181-206. Updated version available in Archives of Indigenous Languages of Latin America <ailla. utexas.org/islandora/object/ailla\%3A124374>.

BASSO, Ellen B. A Kalapalo Grammar, Southern Cariban. 2020. Archives of Indigenous Languages of Latin America <ailla.utexas.org/islandora/object/ailla\%3A271466>.

BASSO, Ellen B. Interpersonal alignments and epistemic marking in Kalapalo (Southern Carib, Brazil). appearing. In BERGOVIST, Henrik; KITTILA, Seppo (Eds.). Evidentiality, egophoricity, and engagement. Language Science Press, $2020 b$.

BYBEE, Joan; PERKINS, R.D.; PAGLICUCA, W. The Evolution of grammar: tense, aspect and modality in the languages of the world. Chicago: University of Chicago Press, 1994.

BYBEE, Joan. Language Change. Cambridge: Cambridge University Press, 2015.

CAMARGO, Eliane. Relaçoes sintáticas e semânticas na predicação nominal do Wayana: a oração com cópula. Amerindia, v. 28, pp. 133-160, 2003.

CARLIN, Eithne. A Grammar ofTrio. A Language of Suriname. Duisburg Papers on Research in Language and Culture, v. 55. Frankfurt am Main: Peter Lang, 2004.

COMRIE, Bernard. Aspect: An Introduction to the study of Verbal Aspect and Related Problems. Cambridge: Cambridge University Press, 1976.

DAHL, Östen. Tense and Aspect Systems. Oxford and New York: Basil Blackwell, 1985.

DAHL, Östen; VELUPILLAI, Viveka. The Perfect. In DRYER, Matthew S.; HASPELMATH, Martin (Eds.). The World Atlas of Language Structures Online. Chapter 68. Leipzig: Max Planck Institute for Evolutionary Anthropology, 2013. Available in <http//wals.info/chapter68>.

DERBYSHIRE, Desmond C. Hixkaryana and Linguistic Typology. Summer Institute of Linguistics Publication No. 76. Arlington, Texas, 1985.

DE VRIES, Lourens. Towards a typology of tail-head linkage in Papuan languages. Studies in Language, V 29, n. 2, pp. 363-384, 2005.

DIXON, R.M.W. Basic Linguistic Theory. Vol .3: Further Grammatical Topics. Oxford: Oxford University Press, 2012.

DU BOIS, John. The stance triangle. In ENGELBRETSON, Robert (Ed.). Stancetaking in discourse: Subjectivity, evaluation, interaction. Amsterdam: John Benjamins, 2007, pp. 139-182. 
FRANCHETTO, Bruna. A fala do chefe: generos verbais entre os Kuikuru do AltoXingu. Cadernos de Estudos Lingiïsticos, v. 4, pp. 45-72, 1983.

FRANCHETTO, Bruna. Ergativity and nominativity in Kuikuro and other Carib languages. In PAYNE, Doris (Ed.). Amazonian Linguistics: Studies in Lowland South American Languages. Austin: University of Texas Press, 1990, pp. 407-427.

FRANCHETTO, Bruna. Rencontres rituelles dans le Haut-Xingu: la parole du chef. In BECQUELIN, Aurore Monod; ERIKSON, Phillipe (Eds.). Les rituelles du dialogue. Nanterre: Société d'Ethnologie, 2000, pp. 481-510.

FRANCHETTO, Bruna. Are Kuikuro roots lexical categories? In LOIS, Ximena; VAPNARSKI, Valentina (Eds.). Polivalency of Roots. Amsterdam: John Benjamins, 2006, pp. 33-68.

FRANCHETTO, Bruna. Absolutivo e ergativo pensados a partir do Kuikuro. Amerindia, v. 32, pp. 38-56, 2008.

FRANCHETTO, Bruna. The ergativity effect in Kuikuro (Southern Carib, Brazil). In Ergativity in Amazonia, Spike Gildea and Francesc Queixalós, eds., 121-158. Philadelphia and Amsterdam: John Benjamins, 2010.

FRANCHETTO, Bruna; SANTOS, G.M. Ferreira dos. Cartography of expanded CP in Kuikuro (Southern Carib, Brazil). In CAMACHO, José; GUTIÉRREZ-BRAVO, Rodrigo; SÁNCHEZ, Liliana (Eds.). Information Structure in Indigenous Languages of the Americas, Syntactic Approaches. New York: De-Gruyter Mouton, 2010, pp. 87-113.

GILDEA, Spike. On reconstructing grammar. Comparative Morphosyntax. Oxford: Oxford University Press, 1998.

GIVÓN, Talmy. Syntax, vol. 1. Amsterdam/Philadelphia: John Benjamins, 2001.

GUERREIRO, Antonio. Ancestrais e suas sombras. Uma etnografia da chefia Kalapalo e seu ritual mortuário. Campinas/SP: Editora Unicamp, 2015.

JAKOBSON, Roman. Shifters, verbal categories and the Russian verb. In Selected Writings 2. Mouton: The Hague, 1971, 130-147.

KOSKRITY, Paul. Getting negatives in Arizona Tewa: On the relevance of Ethnopragmatics and Language Ideologies to Understanding a Case of Grammaticalization. Pragmatics, v. 20, n. 1, pp. 91107, 2010.

LAMBRECHT, Knud. When subjects behave like objects: An analysis of the merging of $S$ and $O$ in sentence focus constructions across languages. Studies in Language, v. 24, n. 3, pp. 611-682, 2000.

MEIRA, Sérgio; FRANCHETTO, Bruna. The Southern languages and the family. International Journal of American Linguistics, v. 71, n. 2, pp. 127-190, 2005.

PAYNE, Thomas E.; PAYNE, Doris L. A Typological Grammar of Panare. A Language of Venezuela. Leiden and Boston: Brill, 2013.

RITZ, Marie-Eve. Perfect tense and aspect. In BINNICK, Robert L. (Ed.). The Oxford Handbook of Tense and Aspect. Oxford: Oxford University Press, 2012, pp. 881-907. 
SANTOS, Gélsama Mara Ferreira dos. Morfologia Kuikuro: as categorias "nome" e "verbo" e os processos de transitivização e intransitivização. 2002, Dissertação. (Mestrado em Estudos Linguísticos), Universidade Federal Rio de Janeiro, Rio de Janeiro, 2002.

STASSEN, Leon. Intransitive Predications. Oxford: Oxford University Press, 2003 [1997].

THOMPSON, Sandra A.; LONGACRE, Robert E.; HWANG, Shin Ja. J. Adverbial clauses. in SHOPEN, Timothy (Ed.). LanguageTypology and Syntactic Description III (ComplexConstructions). 2 ed. Cambridge: Cambridge University Press, 2007, pp. 237-300.

XRAKOVSKIJ, ViktorS. (Ed.). TypologyofTaxis Constructions. LINCOM Studies in Theoretical Linguistics 58. Munich: LINCOM GmbH., 2016. 